\title{
8. Sınıf Öğrencilerinin Liselere Geçiş Sınavı’na (LGS) İlişkin Algılarının Metaforlar Aracılığıyla İncelenmesi
}

\author{
Berru ULUSOY ${ }^{1}$
}

${ }^{1}$ Giresun Üniversitesi, Giresun, Türkiye, kayaberru@gmail.com

\begin{tabular}{|c|c|}
\hline Makale Bilgileri & ÖZ \\
\hline $\begin{array}{l}\text { Makale Geçmişi } \\
\text { Geliş: } 14.06 .2020 \\
\text { Kabul: } 08.10 .2020 \\
\text { Yayın: 29.12.2020 } \\
\text { Anahtar Kelimeler: } \\
\text { Sınav } \\
\text { Liselere Geçiş Sınavı } \\
\text { Metafor }\end{array}$ & $\begin{array}{l}\text { LGS, 8.sınıf öğrencilerinin bir üst öğrenim basamağını belirleme etkisi ile önem teşkil etmektedir. } \\
\text { Belirtilen önem doğrultusunda bu çalışmada 8. sınıf öğrencilerinin LGS'ye ilişkin algıları incelenmiş, ifade } \\
\text { edilen algıların somut örneklerle açıklanabilmesi için metaforlardan yararlanılmıştır. Çalışmada, nitel } \\
\text { araştırma yöntemi kullanılmıştır. Araştırmanın çalışma grubu ise amaçlı örnekleme yöntemlerinden kolay } \\
\text { ulaşılabilir durum örneklemesi/ uygun örnekleme yöntemi ile belirlenen } 175 \text { 8. sınıf öğrencisidir. } \\
\text { Araştırma kapsamındaki } 175 \text { öğrencinin } 86 \text { 'sı kadın, 89'u erkektir. Çalışma grubundan 'LGS' kavramını } \\
\text { tek bir metafor aracılığıyla ifade etmeleri ve kullandıkları metaforların gerekçesini belirtmeleri istenmiştir. } \\
\text { Bu amaçla veriler 'LGS...gibidir, çünkü...' ifadesinin yer aldığ etkinlik formu ile toplanmıştır. Toplanan } \\
\text { verilerin çözümlenmesinde içerik analizinden yararlanılmıştır. Araştırmadan elde edilen bulgulara göre, } \\
\text { çalışmaya katılan öğrencilerin } 77 \text { adet metafor ürettikleri görülmüştür. Üretilen bu metaforlar; 'Rahatsızlık/ } \\
\text { zorluk veren durum olarak LGS (\%38.96), mücadele/ çaba/ emek olarak LGS (\% 23.38), başlangıç / } \\
\text { önemli/ dönüm noktası olarak LGS (\% 15.57), gelecek/ yol gösterici olarak LGS (\% 14.29), başarısızlık } \\
\text { olarak LGS (\% 3.90) ve belirsizlik/ gereksizlik olarak LGS (\% 3.90)' olmak üzere toplam altı kavramsal } \\
\text { kategori altında toplanmıştır. LGS'ye ilişkin metaforların en çok 'Rahatsılık/ zorluk veren durum olarak } \\
\text { LGS kategorisi altında toplandığ1 görülmüştür. Elde edilen bulgular LGS'nin öğrencilerin hayatındaki } \\
\text { önemini ortaya koymakla birlikte LGS'ye ilişkin olumsuz algılarının daha fazla olduğunu göstermiştir. } \\
\text { Genel olarak LGS, öğrencileri rahatsı etmekte ve zorluk veren bir durum olarak algılanmaktadır. }\end{array}$ \\
\hline
\end{tabular}

\section{An Investigation of 8th Grade Student's Perceptions of High School Entrance Exam Through Metaphors}

\begin{tabular}{|c|c|}
\hline Article Info & ABSTRACT \\
\hline $\begin{array}{l}\text { Article History } \\
\text { Received: } 14.06 .2020 \\
\text { Accepted: } 08.10 .2020 \\
\text { Published: } 29.12 .2020 \\
\text { Keywords: } \\
\text { Examination } \\
\text { High School Entrance } \\
\text { Exam } \\
\text { Metaphor }\end{array}$ & $\begin{array}{l}\text { LGS is important with its effect of determining the next higher education level of 8th grade students. In line } \\
\text { with the specified importance in this study, the perceptions of 8th grade students about LGS were examined, } \\
\text { and metaphors were used to explain student perceptions with concrete examples. Qualitative research method } \\
\text { was used in the research and data was collected through metaphors. The study group of the research; } 175 \text { 8th } \\
\text { grade students, which are determined by appropriate sampling method, are among the purposeful sampling } \\
\text { methods. The working group was asked to express the concept of "LGS" through a single metaphor and state } \\
\text { the reason for the metaphors they used. For this purpose, the data is collected with an activity form containing } \\
\text { the expression 'LGS is like, because it is'. Content analysis was used in analyzing the data collection tool. } \\
\text { According to the findings obtained from the study, it was seen that the students who participated in the study } \\
\text { produced } 77 \text { metaphors. These metaphors are; 'LGS as a disturbing / challenging situation (\% 38.96), LGS as } \\
\text { a struggle / effort / labor ( } \% 23.38) \text {, LGS as a starting / important / milestone (\% 15.57), LGS as a future / } \\
\text { guiding ( } \% 14.29 \text { ), LGS as a failure (\% 3.90) and LGS as an uncertainty (\% 3.90). They grouped under a total } \\
\text { of six conceptual categories collected under. The most metaphors related to LGS are gathered under the } \\
\text { category of LGS as disturbance / difficulty (38.96\%). The findings reveal the importance of LGS in student's } \\
\text { lives and show that they have negative perceptions about LGS.In general LGS, disturbs students and it is } \\
\text { perceived as a difficultsituation. }\end{array}$ \\
\hline
\end{tabular}

"This article is licensed under a Creative Commons Attribution-NonCommercial 4.0 International License (CC BY-NC 4.0)"

Atıf/Citation: Ulusoy, B. (2020). 8. sınıf öğrencilerinin liselere geçiş sınavına (LGS) ilişkin algılarının metaforlar aracılığıyla incelenmesi, Necmettin Erbakan Üniversitesi Ereğli Ĕ̈itim Fakültesi Dergisi, 2(2), 186-202. 


\section{GíRIŞ}

Sınav, öğrenmeleri ölçmede ve başarının değerlendirilmesinde kullanılan ölçütlerden biridir (Linn ve Gronlund, 1995). Okullarda, belirlenen hedeflere ulaşma durumu sınavlarla ölçülürken, öğrencilerin üst öğretim kademelerine yerleştirilmeleri için ulusal düzeyde sınavlar düzenlenmektedir (Can, 2017). Öğrenci başarısı yerel ve merkezî olmak üzere iki boyutta değerlendirilmektedir. Öğrencilerin formal eğitim aldıkları okullarda öğretmenleri tarafından sınıf içi başarı durumlarını tespit etmek amacıyla yapılan değerlendirmeler yerel değerlendirme; Millî Eğitim Bakanlığı (MEB), Öğrenci Seçme ve Yerleştirme Merkezi (ÖSYM) gibi merkezî kurumlar tarafından yapışan değerlendirilmeler ise merkezî değerlendirmedir (Çepni, Özsevgeç ve Gökdere, 2003). Okullarda yapılan yerel değerlendirmeler sonucunda başarılı bulunmuş öğrenciler bir üst kademeye geçebilmek için merkezî değerlendirme sınavlarına girer.

Dünyada ortaöğretime yerleştirme sürecinde genel olarak merkezî sınav sonuçlarının ölçüt olarak kullanıldığı (Görmez ve Coşkun, 2015) görülmekle birlikte farklı uygulamalar ile de karşılaşılmaktadır (Gür, Çelik ve Coşkun, 2013). Örneğin Hollanda'da ortaöğretime yerleştirme sürecinde sadece merkezî sınavlar dikkate alınmakta (Aykaç ve Atar, 2014) iken Singapur, Çin, Fransa, Rusya, İtalya gibi ülkelerde ortaokul sonunda bitirme sınavı uygulanarak bu sınav sonucuna göre yerleştirme yapılmaktadır (Wu, 2015). Almanya ve Hindistan'da ise öğrencinin hangi ortaöğretim kurumuna devam edeceğine okul ve aile birlikte karar vermektedir (Jain ve Prasad, 2017). Öğrencilerin bir üst öğrenime geçişlerinin adrese dayalı olarak yapıldığı ülkeler bulunmaktadır. Örneğin Amerika Birleşik Devletleri'nin (ABD) bazı eyaletlerinde adres etkeni dikkate alınmakta (Ergün, 2014), İngiltere'de öğrenciler merkezî sınav olmaksızın ailelere sunulan tercih rehberi ile adreslerine en yakın okula yerleştirilmektedir (Department for Education, England, 2016). Danimarka'da lise eğitim yerlerine kendileri karar veren öğrenciler, genellikle evlerine yakın olan okulları tercih etmektedir. Nitelikli olarak tanımlanan öğrenciler ise bir üst öğrenime, sınav uygulaması sonucunda yerleştirilir (Bökeoğlu ve Özdem, 2009). Finlandiya'da ortaöğretim kurumlarına yerleştirmede okul mezuniyet puanları dikkate alınmaktadır. (Aykaç ve Atar, 2014). Finlandiya'da öğrenciler internet aracılığıyla doldurdukları başvuru formlarına öğrenim görmek istedikleri liseleri yazarak Finlandiya Ulusal Eğitim Kurulu'na teslim etmekte, okullar da mezuniyet puanlarına göre öğrencileri seçmektedir (Eurypedia, 2013).

Türkiye'de ise ortaöğretim kurumlarına öğrenci seçmek için merkezî ölçme ve değerlendirme, MEB tarafından ulusal düzeyde yapılan sınavlar ile yapılmaktadır. Türkiye'de ortaöğretim kurumlarına öğrenci yerleştirmek için 1998-2018 yılları arasında beş farklı sınav sistemi uygulanmıştır. Bunlar; Liselere Giriş Sınavı (LGS 1999-2003), Ortaöğretim Kurumları Seçme ve Yerleştirme Sınavı (OKS 2004-2006), 6, 7 ve 8. sınıflarda yapılan Seviye Belirleme Sınavı (SBS 2007-2013), Temel Eğitimden Ortaöğretime Geçiş (TEOG 2014-2017) ve en son sadece 8. sinıfta uygulanan LGS (2018)'dir (Çelik, 2011). 14 Şubat 2018 tarihinde yeni bir ortaöğretime geçiş sistemi ile uygulamaya konulan LGS'de tüm öğrencilerin sınava girme zorunluluğunun sınav stresine neden olması gerekçesiyle sınava girme zorunluluk olmaktan çıkarılmıştır (MEB Ortaöğretim Kurumları Yönetmeliğinde Değişiklik Yapılmasına Dair Yönetmelik, 2018). Tercihe bağlı olarak girilen LGS'de Bakanlık'ın Kasım 2018'de yapmış olduğu değişiklerle birlikte sınavın birinci bölümünün 50 soruluk sözel alandan (Türkçe: 20, T.C. İnkılap Tarihi: 10, Din Kültürü: 10, İngilizce: 10 soru) ve 75 dakika süre ile uygulanması kararlaştırılmıştır. Sınavın ikinci bölümünde ise 40 soruluk sayısal alan (Matematik: 20, Fen Bilimleri: 20 soru) 80 dakika süre ile gerçekleşmektedir (MEB, 2018).

Öğrenciler, LGS'den aldıkları puan sonucunda çeşitli liselere (Anadolu lisesi, fen lisesi, sosyal bilimler lisesi, mesleki ve teknik Anadolu lisesi) yerleştirilmektedir. Bu liselerden anadolu, fen ve sosyal bilimler liseleri, proje uygulayan eğitim kurumları, mesleki ve teknik anadolu liselerinin anadolu teknik programları nitelikli okullar arasında bulunmaktadır (MEB, 2018). Ortaokuldan mezun olan öğrencilerin ancak \% 10'u nitelikli okullara yerleşebilirken \% 90'ı adrese dayalı kayıt sistemi ile evlerine en yakın beş okuldan tercih ettiği bir okula yerleştirilmektedir. Herhangi bir tercihine yerleşemeyen öğrenciler ise açıköğretim liselerine yönlendirilmektedir. LGS ile okulların nitelik bakımından sınıflandırılması, nitelikli olarak sınıflandırılan 
okullara çok az sayıda öğrencinin yerleşmesi, bu az sayıdaki öğrenci kesimine girebilmek için öğrencilerin birbiriyle yarışması eğitim sisteminde bazı sorunları beraberinde getirmektedir (Demir ve Yılmaz, 2019).

Gür, Çelik ve Coşkun (2013) Türkiye'deki ortaöğretimin en temel sorununun okulların nitelikli ve niteliksiz şeklinde ayrılması olduğunu belirtmiştir. Öztürk ve Aksoy (2014) da öğrenciyi seçen ve okulları sınıflandıran sistemin kesinlikle terk edilmesi gerektiğini savunmaktadır. Can (2015) da çoktan seçmeli teste dayalı merkezî sınavların eğitimde niteliksel gelişmeyi engellediğini, bu yüzden öğretim kademeleri arasındaki geçişlerde sınavların değil, bilgiye ulaşma ve yaşamda kullanma felsefesinin esas alınmasını önermektedir. Dinç, Dere ve Koluman (2014) bu düşüncenin aksine, Türkiye'de sinava giren öğrenci sayısının çok yüksek olması, ortaöğretim okullarının eğitim kalitesi bakımından farklılaşması gibi nedenlerden merkezî sınavların gerekli olduğunu belirtmiştir. Öyle ki Türkiye'de nitelikli okul olarak adlandırılan ve merkezi sınav ile öğrenci alan okullar için 2018 yılında 126.510 kontenjan ayrılmış (MEB, 2018) ancak sınava girmek için 996.000 öğrenci başvuruda bulunmuştur (MEB, 2018). Bu noktada bu okullara yerleşme sürecinin adeta bir yarışa dönüştüğü görülmektedir (Çelik, Boz, Arkan ve Toklucu, 2017). Şad ve Şahiner (2016) çalışmalarında; öğrenci sayısının fazla, nitelikli okul sayısının nispeten az olduğu rekabetçi bir bağlamda, öğrencilerin özelliklerinin doğru bir şekilde ölçülerek başarı sıralarının belirlendiği bir ölçme ve değerlendirme sisteminin gerekli olduğunun altını çizmiştir. Ayrıca ekonomik ve sosyal imkânlar açısından gelişmiş bölgelerdeki öğrenciler ile gelişmemiş bölgelerdeki öğrencilerin eşit koşullarda rekabet edebilmesi için merkezî sınavlar gerekli görülmüştür (Dinç vd., 2014). Alanyazındaki merkezi değerlendirmelerle ilgili bu görüşlerle birlikte öğrencilerin hangi okullara gireceklerini ve hangi tür meslekleri yapacaklarını merkezî sistem sınavlarından elde edilen sonuçlar belirlemektedir. Merkezî sınavlardan biri olan LGS ile ilgili zihinde oluşan şema ve algılar, çeşitli yöntemler ile ifade edilmektedir. Bu yöntemlerden biri de metaforlardır (Kösterelioğlu, 2014).

Metafor; bir kişinin bir kavramı ya da olguyu algıladığı biçimde, benzetmeler kullanarak ifade etmesidir (Aydın, 2010). Aydoğdu (2008) metafor kullanımını, bilinmeyeni bilinenle ilişkilendirerek, kavramlar arasında yeni bağlantılar kurmaya çalışma olarak tanımlamıştır. Böylece metaforlar, yeterince anlaşılmamış konuların daha iyi anlaşılmasına ve düşüncelerin özetlenmesine yardımcı olur (Semerci, 2007). Morgan' a göre (1998) metafor kullanımı, genel olarak dünyayı kavrayışımızı gösteren düşünce biçimi anlamına gelir. $\mathrm{Bu}$ yönüyle metaforlar, bireylerin dünyayı ve kendilerini algılama biçimlerini göstermekte; karmaşık halde bulunan soyut düşüncelerin somutlaştırılmasını sağlamaktadır (Girmen, 2007). 1980'de Lakoff ve Johnson'un "Metaphors We Live By" adlı öncü çalışmasından sonra bir araştırma yöntemi olarak kullanılmaya başlanan metafor, özellikle sürecin içinde yer alan öznelerin kendi deneyimlerini esas alan araştırmalarda giderek daha yaygın kullanılır hale gelmiştir (Yıldız ve Ünlü, 2014). Türkiye'de son yıllarda bir kavrama yönelik algıları belirlemek için metafor çalışmaları yapılmaktadır. Özellikle öğrencinin düşünmesini sağlayan yollardan biri, metaforları kullanmaktır. (Oğuz, 2005).

Türkiye'de 8. sınıf öğrencilerinin daha önce uygulanan SBS, TEOG ile ilgili görüşlerini içeren çalışmalar alanyazında yer almasına rağmen ilk kez 2018 yılında uygulamaya geçen LGS'ye ilişkin algılarının metaforlarla belirlendiği bir çalışma bulunmamaktadır. LGS ile ilgili velilerin, branş öğretmenlerinin görüşlerinin yer aldığ 1 araştırmalar yapılmasına karşın LGS'nin uygulandığ 8 . sınıf öğrencilerinin görüşlerinin metaforik analizinin yapıldığı çalışmaların yer almaması alanyazında eksiklik oluşturmaktadır. Araştırmanın alanyazındaki eksikliği dolduracağı düşünülmektedir. Belirtilen önem doğrultusunda araştırmanın amacı 8. sınıf öğrencilerinin LGS ile ilgili algılarını, metaforlar aracılığıyla ortaya koymaktır. $\mathrm{Bu}$ amaç doğrultusunda çalışmada LGS kavramına yönelik aşağıdaki sorulara cevap aranacaktır.

1-8. sınıf öğrencilerinin LGS'ye ilişkin oluşturdukları metaforlar nelerdir?

2-Öğrencilerin LGS kavramına ilişkin geliştirdikleri metaforlar, ortak özellikleri bakımından hangi kategoriler altında toplanabilir? 


\section{YÖNTEM}

Bu bölümde araştırmanın modeli, çalışma grubu, veri toplama aracı, verilerin toplanması ve verilerin analizi alt başlıklarına yer verilmiştir.

\section{Araştırma Modeli}

Çalışmada nitel araştırma yöntemi kullanılmıştır. LGS'nin 8. sınıf öğrencileri tarafından metafor boyutunda nasıl algılandığı belirlendiğinden araştırmada metaforlar aracılığıyla veriler toplanmıştır. Yıldırım ve Şimşek'e (2008) göre metaforlar eğitim araştırmalarında iki genel amaçla kullanılabilir. Bunlardan birincisi var olan durumu belirlemek, diğeri ise var olan bir süreci iyileştirmektir. Bu araştırmada metaforlar, betimleme amacıyla kullanılmıştır.

\section{Çalışma Grubu}

Araştırmanın çalışma grubunu 2019-2020 eğitim öğretim yılında Ankara ili Mamak ilçe merkezinde bulunan iki ortaokulun 8. sınıflarında öğrenim gören 175 öğrenci oluşturmaktadır. Araştırmada amaçlı örnekleme yöntemlerinden kolay ulaşılabilir durum örneklemesi/ uygun örnekleme yöntemi kullanılmıştır. Amaçlı örnekleme yöntemi; derinlemesine araştırma yapabilmek için çalışmanın amacı bağlamında bilgi açısından zengin durumların seçilmesidir. Amaçlı örneklemede, araştırmacı örnekleme kimlerin seçileceği konusunda araştırmanın amacına uygun örneklemi alır (Balc1, 2011). Bu anlamda, amaçlı örnekleme yöntemleri pek çok durumda, olgu ve olayların keşfedilmesinde ve açıklanmasında yararlı olmaktadır (Tarhan, 2015). Kolay ulaşılabilir durum örneklemesi/ uygun örnekleme yönteminde ise araştırmacı kendine ulaşılması yakın ve kolay durumu seçer. Bu örnekleme yöntemi zaman, para ve işgücü açısından var olan sınırlılıklar nedeniyle örnekleme ulaşmada kolaylık sağlar (Yıldırım ve Şimşek, 2008). Araştırmanın çalışma grubunun cinsiyete göre dağılımı şöyledir:

\section{Tablo 1:}

Öğrencilere İlişkin Kişisel Bilgiler

\begin{tabular}{llll}
\hline \multirow{2}{*}{ Cinsiyet } & & $\mathbf{f}$ & \% \\
& Kadın & 86 & 49 \\
\cline { 2 - 4 } & Erkek & 89 & 51 \\
\hline Toplam & & 175 & 100 \\
\hline
\end{tabular}

Tablo 1 incelendiğinde araştırma kapsamında öğrencilerin 86'sı (\%49) kadın iken, 89'u (\%51) erkek öğrencidir.

\section{Veri Toplama Araçları ve Süreçleri}

Araştırmanın veri toplama aracı oluşturulurken, bireylerin sahip olduğu algıları ortaya çıkarmada metaforların bir araç olarak kullanıldığı ilgili araştırmalar incelenmiştir (Gün, 2015; Gömleksiz, 2016). Yapılan araştırmalarda genellikle katılımcıların açık uçlu cümleleri tamamlamaları istenmiştir. İlgili araştırmalar da dikkate alınarak bu araştırmada 8. sınıf öğrencilerinin LGS'ye ilişkin algılarını belirlemek amacıyla 'LGS....... gibidir, çünkü ...............' ibaresi yazılı yarı yapılandırılmış formlar araştırmanın veri toplama aracı olarak kullanılmıştır.

\section{Verilerin Analizi}

Elde edilen veriler içerik analizi yöntemiyle çözümlenmiştir. İçerik analizi, iletişimin sunulan içeriğinin tarafsız, sistematik ve niceliksel tanımıdır (Berelson 1952). İçerik analizinde temelde yapılan işlem, birbirine benzeyen verileri belirli kavramlar ve temalar çerçevesinde bir araya getirmek ve bunları okuyucunun anlayabileceği bir biçimde organize ederek yorumlamaktır (Yıldırım ve Şimşek, 2008). Janis'a (1949) göre içerik analizi; işaretlerin sınıflanmasıyla araştırmacının ortaya koyduğu yargıların bilimsel rapor olarak değerlendirilmesini sağlar. Bu çalışmanın içerik analizinde Aydın ve Ünaldı (2010) ile Saban (2008) 
tarafından tamamlanan çalışmalarda kullanılan, (1) adlandırma aşaması, (2) tasnif etme aşaması, (3) kategori geliştirme aşaması, (4) geçerlik ve güvenirliği sağlama aşaması ve (5) verileri bilgisayar ortamına aktarma aşamasından oluşan değerlendirme süreci dikkate alınmıştır. Bu işlem basamaklarına göre veri kaynağından elde edilen metaforların analiz edilme aşamaları şöyledir: ilk önce elde edilen metaforlar numaralandırılarak sıralanmış, aynı olanlar gruplanmıştır. Her bir metafor ve nedeni tek tek okunarak kategoriler oluşturulmuştur. Ardından metaforlar kendi kategorilerinde değerlendirilmiştir.

Araştırma verilerinin geçerliğini sağlayabilmek için uzman görüşüne başvurulmuş ve araştırma verilerinin güvenirliğini sağlayabilmek için Miles ve Huberman'ın (1994) geliştirmiş olduğu kodlayıcılar arası güvenirlik hesaplama formülünden (Güvenirlik = Görüş Birliği / Görüş Birliği + Görüş Ayrılığı x 100) yararlanılmıştır. Doktora mezunu öğretmenden metaforları $(\mathrm{f}=77)$ belirlenen kavramsal kategorilere $(\mathrm{N}=6)$ yerleştirmesi istenmiş; seçilen metaforların doğru kategorilere atanıp atanmadıkları kontrol edilmeye çalışılmıştır. Daha sonra, her iki kodlayıcı arasındaki metaforik kodlamalar karşılaştırılmış ve iki kodlayıcı arasındaki güvenirlik \% 98.70 olarak hesaplanmıştır. Nitel araştırmalarda kodlayıcılar arasındaki \% 90 ve üzeri güvenirlik düzeyi oldukça iyi olarak değerlendirilmektedir (Miles ve Huberman, 1994). Çalışmada istenilen güvenirlik düzeyi elde edildiği düşünüldüğünden araştırma bulgularının raporlaştırılması aşamasına geçilmiş ve kategorilere ilişkin metafor örnekleri raporda sunulmuştur. Raporda anlaşılırlığı kolaylaştırmak için oluşturulan ana ve alt kategoriler tablolara yerleştirilmiş tablolardaki veriler ögrencilerin doğrudan alıntılarıyla desteklenmiştir.

\section{Etik}

8. Sınıf Öğrencilerinin Liselere Geçiş Sınavı'na (LGS) İlişkin Algılarının Metaforlar Aracılığıyla İncelenmesi" başlıklı çalışmamın hazırlık, veri toplama, analiz ve bilgilerin sunumu olmak üzere tüm aşamalarından bilimsel etik ilke ve kurallarına uygun davrandınıldığını; bu çalışma kapsamında elde edilmeyen tüm veri ve bilgiler için kaynak gösterildiğini ve bu kaynaklara kaynakçada yer verildiğini; kullanılan verilerde herhangi bir değişiklik yapılmadığını, çalışmanın Committee on Publication Ethics (COPE)' in tüm şartlarını ve koşullarını kabul ederek etik görev ve sorumluluklara riayet edildiğini beyan ederim.

\section{BULGULAR}

Bu kısımda çalışmaya katılan 175 ortaokul 8. sınıf öğrencisinin LGS'ye ilişkin oluşturmuş oldukları metaforlarla ilgili olarak bulgular tespit edilmiştir. Öncelikle elde edilen metaforlar verilmiş daha sonra ise metaforlar ilişkili oldukları kavramsal kategoriler içerisinde sunulmuştur.

Tablo 2.

Araştırmada Üretilen Metaforlar ve Frekans Değerleri

\begin{tabular}{|c|c|c|c|c|c|c|c|}
\hline $\begin{array}{l}\text { Metafor } \\
\text { No }\end{array}$ & Metaforun Ad1 & Frekans $(f)$ & $\begin{array}{l}\text { Yüzde } \\
(\%)\end{array}$ & $\begin{array}{l}\text { Metafor } \\
\text { No }\end{array}$ & Metafor Ad 1 & $\begin{array}{l}\text { Frekans } \\
(f)\end{array}$ & $\begin{array}{l}\text { Yüzde } \\
(\%)\end{array}$ \\
\hline 1 & Gelecekteki hayatım & 30 & 17.14 & 39 & Tek kap1 & 1 & 0.57 \\
\hline 2 & Stres & 12 & 6.86 & 40 & Kader çizgim & 1 & 0.57 \\
\hline 3 & Dönüm noktası & 9 & 5.14 & 41 & Ahiret sinavı & 4 & 2.29 \\
\hline 4 & Zorluk & 20 & 11.43 & 42 & Cehennem azabı & 1 & 0.57 \\
\hline 5 & Korku filmi & 1 & 0.57 & 43 & Ateş & 1 & 0.57 \\
\hline 6 & Şans çark1 & 1 & 0.57 & 44 & Korku tüneli & 1 & 0.57 \\
\hline 7 & Önemli sınav & 6 & 3.43 & 45 & Yol & 1 & 0.57 \\
\hline 8 & Çizgi & 1 & 0.57 & 46 & $\begin{array}{l}\text { Matematik } \\
\text { sinavi }\end{array}$ & 1 & 0.57 \\
\hline 9 & Son ve başlangıç & 1 & 0.57 & 47 & Emek & 8 & 4.57 \\
\hline 10 & Yeni okul & 1 & 0.57 & 48 & Ölüm & 1 & 0.57 \\
\hline
\end{tabular}




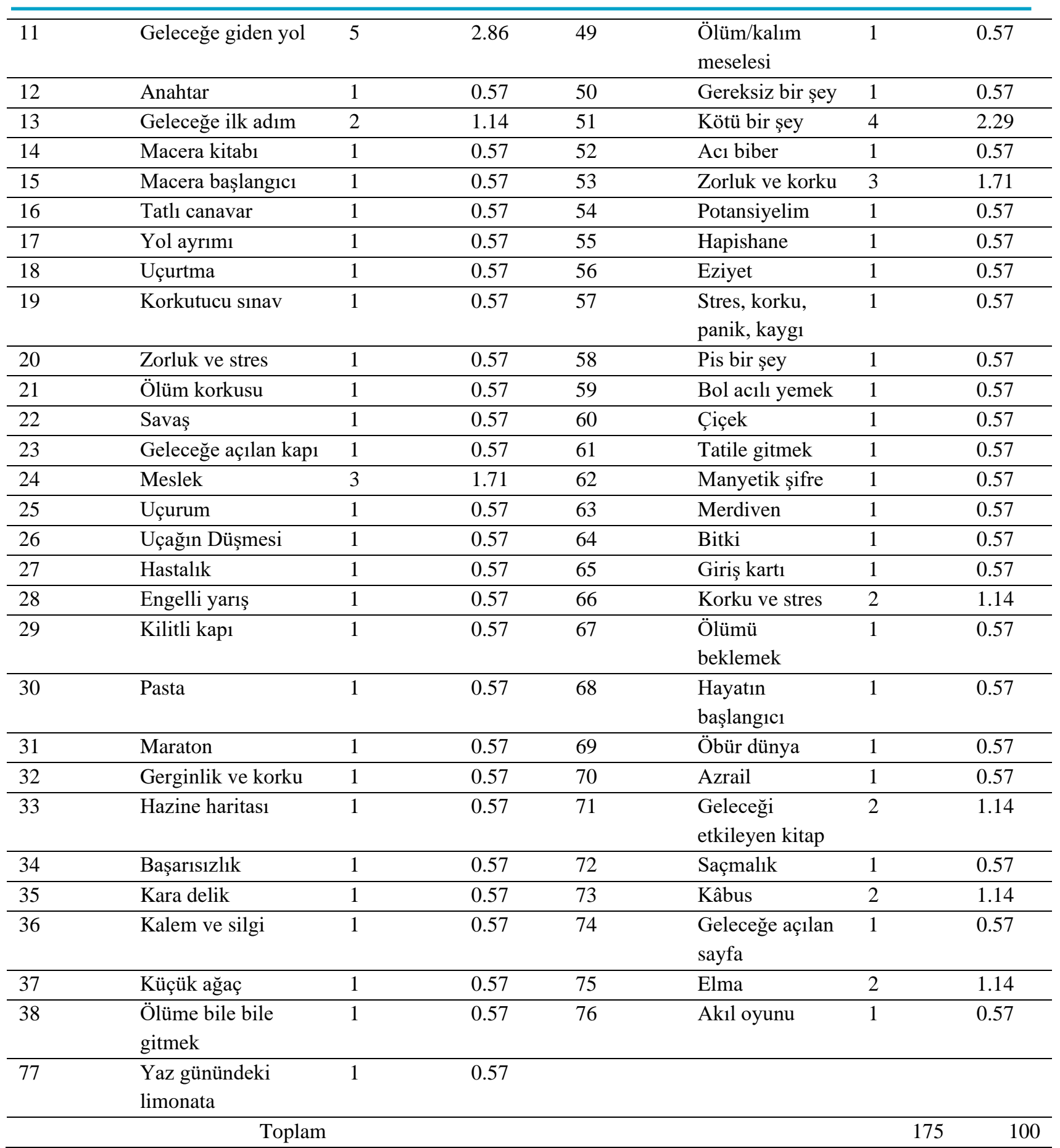

Tablo 2'de araştırmaya katılan 175 ortaokul 8. sınıf öğrencisinin oluşturmuş oldukları metaforlar, frekans ve yüzdeleri ile birlikte sunulmuştur. Araştırmaya katılan öğrenciler LGS kavramına yönelik toplam 77 metafor geliştirmiştir. LGS'ye ilişkin en çok kullanılan metafor, gelecekteki hayatım' ( $\mathrm{f}=30, \% 17.14$ ) metaforu olmuştur. Bunun dışında zorluk ( $\mathrm{f}=20, \% 11.43$ ), stres ( $\mathrm{f}=12, \% 6.86)$, dönüm noktası ( $\mathrm{f}=9, \% 5.14)$, emek ( $\mathrm{f}=8, \%$ 4.57), sıkça kullanılan metaforlardır. Araştırmada, öğrencilerin LGS kavramına yönelik olarak geliştirdikleri metaforlar altı kavramsal kategori altında toplanmıştır. Araştırmaya katılan öğrencilerin LGS kavramına yönelik geliştirdikleri metaforların içerisinde yer aldığı kavramsal kategoriler Tablo 3'te sunulmuştur. 
Tablo 3.

8. Sinıf Öğrencilerinin LGS'ye İlişkin Geliştirdikleri Metafor Kategorileri

\begin{tabular}{|c|c|c|c|c|}
\hline Kategoriler & Metafor Adlar1 & Metafor Say1s1 & $\begin{array}{l}\text { Metafor } \\
\text { Frekans1 } \\
\text { (Öğrenci } \\
\text { Sayısı) }\end{array}$ & $\begin{array}{l}\text { Metafor } \\
\text { Yüzdesi (\%) }\end{array}$ \\
\hline $\begin{array}{l}\text { Rahatsızlık/ zorluk } \\
\text { veren durum olarak } \\
\text { LGS }\end{array}$ & $\begin{array}{l}\text { 1-Stres (12), 2-zorluk (20), 3-korku filmi (1), } \\
\text { 4-Korkutucu sınav (1), 5-Zorluk ve stres (1) 6- } \\
\text { Ölüm korkusu (1)7-Uçurum (1) 8- Hastalı (1) } \\
\text { 9- Engelli yarış (1) 10-Gerginlik ve korku (1) } \\
\text { 11-Akıl oyunu (1), 12-Korku ve stres (2), 13- } \\
\text { Ölümü beklemek (1)14-Azrail (1) 15-Ahiret } \\
\text { sınavı (4) } \\
\text { 16-Cehennem azabı (1) 17-Ateş (1) 18-Korku } \\
\text { tüneli (1) 19-Matematik sınavı (1) 20-Kâbus } \\
\text { (2) 21-Ölüm (3) 22-Kötü bir şey (4) 23-Acı } \\
\text { biber (1) 24-Zorluk ve korku (3) 25-Hapishane } \\
\text { (1) 26-Eziyet (1) 27-Stres, korku, panik, kayg1 } \\
\text { (1) 28-Pis bir şey (1) 29-Bol acılı yemek (1) } \\
\text { 30- Uçağın düşmesi (1) }\end{array}$ & 30 & 70 & 38.96 \\
\hline $\begin{array}{l}\text { Mücadele/ çaba/ emek } \\
\text { olarak LGS }\end{array}$ & $\begin{array}{l}\text { 1-Bitki (1)2-Çiçek (1) } \\
\text { 3-Tatile gitmek (1) 4-Şans çarkı (1) 5-Uçurtma } \\
\text { (1)6-Savaş (1) 7-Macera kitabı (1) 8-Tatlı } \\
\text { canavar (1)9-Kilitli kapı (1) 10-Pasta (1)11- } \\
\text { Maraton (1) 12-Küçük ağaç (1) 13-Elma } \\
\text { (2)14- öbür dünya (1)15.Emek (8)16- } \\
\text { Potansiyelim (1)17-Yol (1) 18- Yaz günündeki } \\
\text { limonata (1) }\end{array}$ & 18 & 26 & 23.38 \\
\hline $\begin{array}{l}\text { Başlangıç/ önemli } \\
\text { /dönüm noktası olarak } \\
\text { LGS }\end{array}$ & $\begin{array}{l}\text { 1-Giriş kartı (1), 2-Dönüm noktası (9),3-Çizgi } \\
\text { (1) 4-Son ve başlangıç (1)5-Yeni okul (1)6- } \\
\text { Macera başlangıcı (1)7-Yol ayrımı (1) 8- } \\
\text { Hayatın başlangıcı (1) 9-Manyetik şifre (1)10- } \\
\text { Önemli sınav (6)11-Ölüm/kalım meselesi } \\
\text { (1)12-Kader çizgim (1) }\end{array}$ & 12 & 25 & 15.57 \\
\hline $\begin{array}{l}\text { Gelecek/ yol gösterici } \\
\text { olarak LGS }\end{array}$ & $\begin{array}{l}\text { 1-Gelecekteki hayatım (30), 2- geleceğe giden } \\
\text { yol (5), 3-anahtar (1), 4-geleceğe ilk adım (2), } \\
\text { 5-meslek (3), 6- geleceğe açılan sayfa (1), 7- } \\
\text { geleceği etkileyen kitap (2), 8-tek kapı (1), 9- } \\
\text { Geleceğe açılan kapı (1) 10-Merdiven (1)11- } \\
\text { Hazine haritası(1) }\end{array}$ & 11 & 48 & 14.29 \\
\hline $\begin{array}{l}\text { Başarısızlık olarak } \\
\text { LGS }\end{array}$ & $\begin{array}{l}\text { 1-Ölüme bile bile gitmek (1)2-Kalem ve silgi } \\
\text { (1) 3-Başarısızlık (1) }\end{array}$ & 3 & 3 & 3.90 \\
\hline $\begin{array}{l}\text { Belirsizlik/gereksizlik } \\
\text { olarak LGS }\end{array}$ & $\begin{array}{l}\text { 1-Kara delik (1) 2-Gereksiz bir şey (1) 3- } \\
\text { Saçmalık(1) }\end{array}$ & 3 & 3 & 3.90 \\
\hline
\end{tabular}


Çalışmada ortaya çıkan bu kavramsal kategorilerin; rahatsızlık/zorluk veren durum olarak, mücadele/ çaba/ emek olarak, başlangıç/ önemli /dönüm noktası olarak, gelecek/ yol gösterici olarak, başarısızlık olarak, belirsizlik/gereksizlik olarak LGS biçiminde oldukları belirlenmiştir. LGS'ye yönelik yapılan 77 metafor kategorileştirildiğinde metaforların en çok rahatsızlık/ zorluk veren durum olarak LGS (\% 38.96) kategorisi altında toplandığı görülmektedir. Bu kategoriyi mücadele/ çaba/ emek olarak LGS (\% 23.38), başlangıç/ önemli /dönüm noktası olarak LGS (\% 15.57), gelecek/ yol gösterici olarak LGS (\% 14.29) kategorileri takip etmektedir. LGS'ye ilişkin metaforlar en az başarısızlık olarak LGS (\% 3.90) ve belirsizlik/gereksizlik olarak LGS (\% 3.90) kategorisi altında sınıflandırılmıştır.

\section{Kavramsal Kategorilere İlişsin Bulgular}

Araştırmanın bu bölümünde, çalışmaya katılan öğrenciler tarafından LGS kavramına ilişkin üretilen metaforlar kavramsal kategoriler altında ele alınarak incelenmiştir.

\section{1-Rahatsılık/Zorluk Veren Durum Olarak LGS}

Araştırmanın merkezi sistem sınavları metaforuna ilişkin elde edilen ilk kavramsal kategorisi 'rahatsızlık/ zorluk veren durum olarak LGS' dir. Toplamda 175 öğrenciden 70 öğrencinin, toplamda 77 adet metaforun 30'unu (\% 38.96) üretmesiyle bu kategori, en fazla metafor oluşturulan kategoridir. Bu kavramsal kategori içerisinde en yüksek frekansa sahip metaforlar sırasıyla şu şekildedir: zorluk $(f=20)$, stres $(f=12)$, ahiret sinavı ( $f=4)$, kötü bir şey ( $f=4)$, ölüm $(f=3)$, korku ve stres $(f=2)$, kâbus $(f=2)$, korku filmi $(f=1)$, korkutucu sınav ( $f=1)$, zorluk ve stres $(f=1)$, ölüm korkusu $(f=1)$, uçurum $(f=1)$, hastalık $(f=1)$, engelli yarış $(f=1)$, gerginlik ve korku $(f=1)$, akıl oyunu $(f=1)$, ölümü beklemek $(f=1)$, Azrail $(f=1)$, cehennem azabı $(f=1)$, ateş $(f=1)$, korku tüneli $(f=1)$, matematik sınavı $(f=1)$, acı biber $(f=1)$, zorluk ve korku $(f=$ 3), hapishane ( $f=1)$, eziyet $(f=1)$, stres, korku, panik, kaygı $(f=1)$, pis bir şey $(f=1)$, bol acılı yemek $(f=$ 1), uçağın düşmesi ( $\mathrm{f}=1)$.

Öğrencilerin oluşturdukları metaforlar aşağıda yer alan örneklerdeki gibi tanımlanmıştır:

"LGS; korka korka korku filmi izlemek gibidir. Çünkü korku hat safhadadır fakat asla filmi izlemekten vazgeçmem.',

"LGS; stres gibidir. Çünkü bu sınavda kaybettiğim her soruyla beraber hayallerim de kaybolacakmış gibi hissediyorum."

"LGS; stres gibidir. Çünkü sınav yüzünden psikolojik sıkıntılar yaşıyorum."

"LGS; uçurum gibidir. Çünkü tek hatada ölürsün."

"LGS; uçak gibidir. Çünkü düşerse ölürsün."

"LGS; hastalık gibidir. Çünkü insanın canını yakar.",

"LGS, yaşayıp yaşayabileceğim en kötü kâbus gibidir. Çünkü MEB hiç yaşamadığım kadar stresi bana bir yılda yaşatıoor."

"LGS, Azrail gibidir. Çünkü beni öldürüyor.",

"LGS, çok zor bir sınav gibidir. Çünkü zaman çok olmasına rağmen sorular çok zor ve uzun."”

"LGS; korku tüneli gibidir. Çünkü çevremdeki baskı beni korkutuyor.',

"LGS; zorluk gibidir. Çünkü sorular çok zor ve sınav sistemi sürekli değişiyor. Biz deneme tahtası olduk."”

"LGS; kâbus gibidir. Çünkü hayatımızı acımasızca alt üst eder."

"LGS; bol acılı bir yemek gibidir. Çünkü acı faydalıdır ama acının da fazlası zarardır.", 
“LGS; çok pis bir şey gibidir. Çünkü LGS’yi sevmiyorum, psikolojimi bozuyor.”"

"LGS; hapishane gibidir. Çünkü yüksek puan alan beraat ediyor, düşük not alan da hapishanede eziyet görüyor."

\section{2-Mücadele/Çaba/Emek Olarak LGS}

LGS metaforuna ilişkin elde edilen ikinci kavramsal kategori "mücadele/ çaba/ emek olarak LGS" dir. Bu kategoride 26 öğrencinin, toplamda 77 adet metaforun 17'sini (\% 23.38) ürettikleri görülmüştür. Bu metaforlar içerisinde en yüksek frekansa sahip metaforlar sırasıyla şu şekildedir: emek $(f=9)$, elma $(f=2)$, bitki $(\mathrm{f}=1)$, çiçek $(\mathrm{f}=1)$, tatile gitmek $(\mathrm{f}=1)$, şans çarkı $(\mathrm{f}=1)$, uçurtma $(\mathrm{f}=1)$, savaş $(\mathrm{f}=1)$, macera kitabı $(\mathrm{f}=1)$, tatlı canavar $(\mathrm{f}=1)$, kilitli kapı $(\mathrm{f}=1)$, pasta $(\mathrm{f}=1)$, maraton $(\mathrm{f}=1)$, küçük ağaç $(\mathrm{f}=1)$, öbür dünya $(\mathrm{f}=1)$, potansiyelim ( $\mathrm{f}=1)$, yol $(\mathrm{f}=1)$.

Öğrencilerin LGS'ye ilişkin ürettikleri metaforlar ikinci kavramsal kategori içinde incelendiğinde, üretilen metaforların genel olarak öğrenciler açısından mücadele gerektiren, çaba ve emeğe bağlı olduğu bulgusuna ulaşılmıştır. Aşağıda öğrencilerin ifadelerinden örnekler sunulmuştur:

"Şans çarkı gibidir. Çünkü ne kadar güçlü çevirirsen o kadar şanslı olursun.",

“LGS, macera kitabı okumak gibidir. Çünkü bütün zorluklara rağmen pes etmeyen kahramanlar mutlu sona ulaşır.'

“LGS, uçurtma gibidir. Çünkü uçurtmayı doğru yönde uçurmaya çabalarsan yükselir.'

“LGS, başarıya yönelik savaş gibidir. Çünkü savaştığın çok güçlü.'

"LGS, kocaman bir sürü kilidi olan kapı gibidir. Çünkü kilidi açmak benim elimde."

"LGS, pasta gibidir. Çünkü pasta zor yapılır ama sonucunda tadı çok güzel olur.",

"LGS, bir atletin aylar boyunca hazırlandığı maraton gibidir. Çünkü biz de atletlerin yaptığı antrenmanlar gibi disiplinli olarak çalışıoruz. Beslenme ve uyku düzenimize dikkat ediyoruz. Maratona benzetme nedenim ise, aylarca çalışıp sadece bir maçta kendimizi gösterecek olmamız ."

“LGS; yaz günündeki limonata gibidir. Çünkü bizi ferahlatır fakat yapımı zordur.",

“LGS, küçük bir ağaç gibidir. Çünkü LGS’ye girdikten bir kaç sene sonra üniversite sınavına gireceğiz ve o ağacı büyüteceğiz."”

"LGS, elma gibidir. Çünkü o elmayı kırmızısından yersen her şey tatlı olur, ekşisinden yersen sevilmez. Bu bizim elimizdedir. Ne seçersek odur."

"LGS, öbür dünya gibidir. Çünkü eğer çabalarsan iyi tarafa gidersin, çalışmazsan kötü tarafa gidersin."

"LGS; elma gibidir. Çünkü elmayı bitirebilmek için çaba sarf etmemiz gerekir."

"LGS, emek vermemizi sağlayan bir firsat gibidir. Çünkü sadece başarılı öğrencileri seçer. Başarılı öğrenciler de çalışıp emek verenlerdir.',

"LGS, tatile gitmek gibidir. Çünkü tatile gitmek için paraya, LGS'ye girmek için de bilgiye ihtiyaç vardır."

"LGS, çiçek gibidir. Çünkü çiçek güzeldir ama zamanla, emekle oluşur."

\section{3-Başlangıç/Önemli /Dönüm Noktası Olarak LGS}

LGS metaforuna ilişkin elde edilen üçüncü kavramsal kategoriyi "başlangıç/ önemli /dönüm noktası olarak LGS” oluşturmaktadır. Bu kategoride 25 öğrencinin, toplamda 77 metafordan 12'sini (\%15.57) ürettikleri görülmüştür. Bu metaforlar içerisinde en yüksek frekansa sahip metaforlar sırasıyla şu şekildedir: dönüm 
noktası ( $f=9$ ), önemli sınav ( $f=6)$, çizgi $(f=1)$, giriş kartı $(f=1)$, son ve başlangıç $(f=1)$, yeni okul $(f=1)$, macera başlangıcı $(\mathrm{f}=1)$, yol ayrımı $(\mathrm{f}=1)$, hayatın başlangıcı $(\mathrm{f}=1)$, manyetik şifre $(\mathrm{f}=1)$, önemli sınav $(\mathrm{f}=6)$, ölüm/kalım meselesi ( $\mathrm{f}=1)$, kader çizgim $(\mathrm{f}=1)$.

Öğrencilerin LGS'ye ilişkin ürettikleri metaforlar incelendiğinde, üretilen metaforların genel olarak öğrenciler tarafından çok önemli, hayatlarında bir dönüm noktası ve başlangıç olduğu görülmektedir. Aşağıda öğrencilerin LGS'ye ilişkin algılarından örnekler sunulmuştur:

"LGS, iki yol ayrımı gibidir. Çünkü bu yollar iyi lise veya kötü liseye gidiyor."

"LGS, hayatın başlayışı gibidir. Çünkü ortaokuldan sonra güzel bir iş için atılan ilk adımdır."

"LGS, hayatımın dönüm noktası gibidir. Çünkü gideceğim üniversiteyi belirleyecek aşamalardan biri. Güzel bir lise, güzel bir üniversiteye kapı açar.',

"LGS, manyetik şifre gibidir. Çünkü kartı okutmadan istediğimiz yere giremiyorsak, sınava girmeden de istediğimiz yere gidemeyiz."

\section{4-Gelecek/ Yol Gösterici Olarak LGS}

LGS metaforuna ilişkin dördüncü kategoriyi "gelecek/ yol gösterici olarak LGS” oluşturmaktadır. Bu kategoride 48 öğrenci, toplamda üretilen 77 adet metaforun 11'ini (\%14.29) üretmiştir. Bu metaforlar içerisinde en yüksek frekansa sahip metaforlar sırasıyla şu şekildedir: gelecekteki hayatım ( $\mathrm{f}=30)$, geleceğe giden yol ( $f=5)$, meslek $(f=3)$, geleceğe ilk adım $(f=2)$, geleceği etkileyen kitap $(f=2)$, anahtar $(f=1)$, geleceğe açı1lan sayfa $(f=1)$, tek kapı $(f=1)$, geleceğe açılan kapı $(f=1)$, merdiven $(f=1)$, hazine haritası (f=1).

Öğrenciler tarafindan oluşturulan bazı metafor örnekleri aşağıda sunulmuştur.

“Hayatımı belirleyecek bir sınav gibidir. Çünkü geleceğimin iyi ya da kötü olması bu sınava bağlı.”

“Geleceğe dair anahtar gibidir. Çünkü LGS'den yüksek alırsak gelecekteki tüm kapılar bu anahtarla açılır.',

“Geleceğe ilk adımım gibidir. Çünkü bu sınav beni önce liseye, sonra üniversiteye götürecek.’”

“LGS, hazine haritası gibidir. Çünkü harita bizi nasıl ki hazineye götürürse bizi en çok istediğimiz liseye götürecek sinav da odur.',

“'LGS, hayatımı değiştiren gelecek gibidir. Çünkü o sınav sayesinde geleceğimiz parlak olabilir ve rahat bir hayat süreriz."

“LGS, hayatımın sonuna kadar etkileyecek önemli bir kitap gibidir. Çünkü sınavdan alacağım puan hayatımın sonuna kadar beni etkileyecek."

“'LGS, hayatımın geri kalanını belirleyen gelecek gibidir. Çünkü o sınav, gideceğimiz üniversiteyi etkiler, o üniversite işimizi belirler, işimiz de hayatımızı etkiler."

“LGS, merdiven gibidir. Çünkü bu sınavla bizi geleceğe çıkartan katları çıkarız.”,

\section{5-Başarısızlık Olarak LGS}

LGS metaforuna ilişkin elde edilen beşinci kavramsal kategoriyi 'başarısızlık olarak LGS' oluşturmaktadır. Bu kategoride 3 öğrencinin, 3 (\% 3.95) adet metafor ürettikleri görülmüştür. Bu metaforlar şunlardır: ölüme bile bile gitmek ( $f=1)$, kalem ve silgi $(f=1)$, başarısızlık ( $f=1$ ). Beşinci kategori içinde üretilen metaforların öğrenciler açısından başarısızlı̆̆ çağrıştırdığı anlaşılmıştır. Örneğin, bir öğrenci LGS'yi “Ölüme bile bile gitmek gibidir. Çünkü önyargılarımız bizi öldürüyor' ifadesiyle açıklamıştır. Öğrencilerin LGS'ye ilişkin algılarından örnekler aşağıda sunulmuştur:

"LGS, benim yapamayacağım bir sınav gibidir. Çünkü derslerim de iyi değil.", 
"LGS, kalem ve silgi gibidir. Çünkü kalem ne kadar yazsa ve çalışsa da silgi hepsini bir anda siler."

\section{6-Belirsizlik/Gereksizlik Olarak LGS}

LGS'ye ilişkin elde edilen altıncı kavramsal kategoriyi "belirsizlik/ gereksizlik Olarak LGS” oluşturmuştur. Bu kategoride 3 öğrencinin, 3 (\% 3.95) adet metafor ürettikleri görülmüştür. Bu metaforlar şunlardır: kara delik ( $\mathrm{f}=1)$, gereksiz bir şey $(\mathrm{f}=1)$, saçmalık $(\mathrm{f}=1)$. Beşinci kategori içinde üretilen metaforlarda görüldüğü üzere öğrenciler LGS'yi gereksiz ve saçma bir sınav olarak görmekle birlikte belirsizlik yaratan bir durum olduğunu belirtmektedir. Örneğin;

"LGS, kara delik gibidir. Çünkü hem kara deliğin içini merak ederiz hem de içine girersek sonunun ne olacağını bilemeyiz.",

"LGS, saçmalık gibidir. Çünkü çok gereksiz."

“LGS, gereksiz bir sınav gibidir. Çünkü sınava gerek yok.

\section{TARTIŞMA / SONUÇ / ÖNERILER}

Bu çalışmada 8. sınıf öğrencilerinin LGS'ye ilişkin düşünceleri, metaforlar aracılığıyla ortaya koyulmuştur. Araştırmaya katılan öğrenciler LGS kavramı ile ilgili olarak toplam 77 metafor üretmiştir. Bu metaforlar; rahatsızlık/ zorluk veren durum olarak LGS (\% 38.96), mücadele/ çaba/ emek olarak LGS (\% 23.38), başlangıç / önemli/ dönüm noktası olarak LGS (\% 15.57), gelecek/ yol gösterici olarak LGS (\% 14.29), başarısızlık olarak LGS (\% 3.90) ve belirsizlik/ gereksizlik olarak LGS (\% 3.90) olmak üzere toplam altı kavramsal kategori altında toplanmıştır.

Yapılan araştırmada elde edilen ilk kavramsal ve en çok metaforun yapıldığı kategori; rahatsızlık/ zorluk veren durum olarak LGS'dir. Bu kategoride toplam 70 öğrencinin 30 adet metafor ürettikleri görülmüştür. Bu metaforların içerisinde en yüksek frekansa sahip metaforlar zorluk, stres, ahiret sınavı, kötü bir şey ve ölümdür. Öğrencilerin LGS'ye ilişkin ürettikleri metaforlar incelendiğinde, üretilen metaforların genel olarak öğrenciler açısından stres, korku, kaygı, zorluk ve rahatsızlık veren yapıda olduğu anlaşılmıştır. Alanyazın incelendiğinde sınavların özellikle de merkezi sınavların öğrencilerde stres ve kaygıya neden olduğunu belirtilmiştir (Jones vd., 1999; Ocak, Akgül ve Yıldız, 2010; Yavuz, 2010; Şahin, Uz Baş, Şahin Frrat ve Sucuoğlu, 2012; Dinç vd. 2014; Karadeniz, Er ve Tangülü, 2014; Şad ve Şahiner, 2016; Demir ve Yılmaz, 2019). Örneğin Karadeniz vd. (2014) çalışmalarında öğrenciler sınavları 'işkence, eziyet, ölüm, ölüm korkusu' gibi metaforlar ile tanımlamıştır.

Öztürk ve Aksoy (2014) araştırmasında sınavların varlığının bir stres kaynağı olarak algılandığını belirtmiştir. Ayrıca Güngör Aytar ve Kurtoğlu Karataş (2017) üniversite sınavına ilişkin metaforları incelemiş, sınavların kaygı ve korku yarattığı bulgusuna ulaşmışlardır. Bu bulgu Koçak, Doğan Gül, Gül ve Çokluk Bökeoğlu (2017)'nun sınavın sıkıcı, korkutan, kaygılandıran ve tehlikeli bir yapıda olduğunu belirten çalışma bulgularıyla benzerlik taşımaktadır. Duban ve Arısoy (2017) da 8. sınıf öğrencilerinde sınavın stres, kaygı ve korkuya neden olduğunu, bu durumun da öğrencinin yaşantısını olumsuz etkilediğini belirtmiştir. Benzer şekilde Eren ve Tekinarslan (2013,) araştırmalarında, sınavların yetişkinlerde bile korku, kaygı, stres yaratan bir kâbus olarak algılandığını vurgulamıştır. Dönmez (2017) ise öğrencilerin, karşılaştıkları bu gerçeği kabul etmek zorunda kaldıklarını ve tüm yaşamlarını sınav kaygısıyla yaşamaya alıştıklarını ifade etmiştir.

Aslan ve Cansever'e (2009) göre henüz çocukluk dönemini yaşayan öğrencilerin merkezî sınavlarla ilk kez karşılaşması onları oyundan, aileden ve sosyal yaşamdan izole edilerek tamamen sınav odaklı bir yaşantı sürdürmesine, stres, korku ve kaygı yaşamasına neden olmaktadır. Stres ve kaygı gibi etkenler aslında motivasyon artırıcı bir etkiye de sahiptir. Fakat çocuğun yaşamının sınav etrafında oluşması, sınava verilen aşırı önem bu stres ve kaygı düzeyinde artış meydana getirerek çocuğun psikolojik sağlığının olumsuz etkilenmesine yol açar (Şad ve Şahiner, 2016). Her ne kadar 14 Şubat 2018 tarihinde uygulamaya konulan 
yeni ortaöğretime geçiş sistemi ile öğrencilerin daha fazla sosyalleşmesi, stres ve kaygı düzeyinin azaltılması amaçlanmış ve sınava girmek isteğe bağlı hale getirilmiş olsa da ortaokul son sınıf öğrencilerinin neredeyse tamamına yakını sınava girmektedir (Güler, Arslan ve Çelik, 2019).

LGS metaforuna ilişkin elde edilen ikinci kavramsal kategori 'mücadele/ çaba/ emek olarak LGS'dir. Bu kategoride toplam 26 öğrencinin, 17 adet metafor ürettikleri görülmüştür. Bu metaforlar içerisinde en yüksek frekansa sahip metafor, 'emek'tir. Karadeniz vd. (2014) yaptıkları araştırmada, 8. sınıfta yapılan sınavın öğrenciler tarafından bir yarış olarak algılandığını ortaya koymuştur. Baş ve Kıvılcım (2019) merkezî sistem sınavlarına ilişkin öğrencilerin ürettikleri metaforları incelemiş, üretilen metaforların genel olarak öğrenciler açısından çaba ve çalışma gerektirdiği sonucuna ulaşmıştır. Merkezî sistem sınavları bu yönüyle öğrenciler arasındaki rekabeti ve gösterilen çabayı artırmakta (Büyüköztürk, 2016) öğrenciler başarılı olmaları için daha çok mücadele etmeye, yarışmaya zorlanmaktadır (Karaşahinoğlu, 2015). Bu da LGS'nin eğitim sistemindeki rekabetçi ortamı artırmasıyla üzerinde tartışılması gereken bir konudur.

LGS metaforuna ilişkin elde edilen üçüncü kavramsal kategoriyi 'başlangıç/ önemli /dönüm noktası olarak LGS' oluşturmaktadır. Bu kategoride 25 öğrencinin, 12 adet metafor ürettikleri görülmüştür. Bu metaforlar içerisinde en yüksek frekansa sahip metaforlar 'dönüm noktası' ve ‘önemli sınav'dır. Sarı'ya (2016) göre de Türkiye'deki merkezî sistem sınavlar, öğrenciler için geleceği belirleyecek dönüm noktası anlamına gelmektedir. Tuncer'e (2017) göre merkezî sınavlar öğrencilerin hayatlarını etkileyen önemli bir dönüm noktası olduğundan oldukça önemlidir. Dönmez (2017) araştırmasında, temel eğitimden ortaöğretime geçişte merkezî sınavların, öğrencilerin davranışları ve yaşantıları üzerinde önemli ölçüde etki bıraktığı bulgusuna ulaşmıştır. Blake (2012) merkezi sınavların; öğrencilerin yaşamları üzerinde etkileri olması nedeniyle önemli olduğunu belirtmiştir.

LGS metaforuna ilişkin elde edilen dördüncü kavramsal kategoriyi 'gelecek/ yol gösterici olarak LGS' oluşturmaktadır. Bu kategoride 48 öğrencinin 11 adet metafor ürettikleri görülmüştür. Bu metaforlar içerisinde en yüksek frekansa sahip metaforlar 'gelecekteki hayatım', 'geleceğe giden yol' ve 'meslek'tir. Araştırma bulgularına bakıldığında öğrencilerin gelecekteki yaşamlarını LGS ile ilişkilendirdikleri görülmüştür. Elde edilen bu bulguyu Karaşahinoğlu'nun (2015) yapmış olduğu çalışma desteklemektedir. Belirtilen çalışmada öğrencilerin büyük bir kısmına göre sınav; onların geleceklerini ve yaşam standartlarını belirlemektedir. Aynı görüş doğrultusunda Çelik (2011), İnanç ve Hanımoğlu (2011) Türkiye'de merkezî sistem sınavlarının öğrencilerin iş ve mesleklerini, gelecekteki hayatlarını belirlediğini belirtmiştir. Sarıer'e (2010) göre de özellikle ortaöğretime giriş sınavları, öğrencileri bir mesleğe hazırlamaktadır.

Araştırmadaki beşinci kavramsal kategori 'başarısızlık olarak LGS' dir. Bu kategoride 3 öğrenci, 3 adet metafor üretmiştir. Bu metaforlar; 'ölüme bile bile gitmek, kalem ve silgi, başarısızlıktır'. Araştırmadan elde edilen bulguya göre öğrenciler LGS'ye karşı önyargılı yaklaşmakta ve LGS'yi başarılamayacak bir sınav olarak görmektedir. Çetin ve Ünsal'ın (2019) yapmış oldukları çalışma bulgusuna göre de öğrenciler merkezî sınavda başarısız olacaklarını düşünmektedir. Uşaklı ve Yapıcı (2001) öğrencilerin yaşadıkları sınav kaygısı ile kendilerinin sınavda başarılı olamayacaklarını, sınav sonunda her şeyin berbat olacağını düşünmeleri gibi bilişsel olarak olumsuz düşünceler geliştirebileceğini belirtmiştir. Erözkan (2004) da başa çıkılmaz derecedeki kaygıya bağlı olarak ortaya çıkan bu olumsuz düşüncelerin başarısızlığı ortaya çıkardığını ifade etmiştir. Bolat (2010) öğrencilerin sınava karşı önyargılı tutumlarının ve başarısızlığı kabullenmelerinin başarısızlık getirdiğinin altını çizmiştir.

LGS'ye ilişkin elde edilen altıncı kavramsal kategoriyi 'belirsizlik/ gereksizlik olarak LGS' oluşturmaktadır. Bu kategoride 3 öğrencinin, 3 adet metafor ürettikleri görülmüştür. Bunlar; kara delik, gereksiz bir şey ve saçmalıktır. Edinilen bu bulgulara göre öğrenciler LGS'nin kendileri için gereksiz bir sınav olduğunu ve belirsizlik taşıdığını düşünmektedir. Benzer olarak Baş ve Kıvılcım (2019) da çalışmalarında öğrencilerin merkezi sistem sınavlarını genel olarak sonucu belli olmayan bir kavram olarak algıladıkları bulgusuna ulaşmıştır. Güven ve Dak (2017) tarafından yapılan çalışmada ise KPSS'ye yönelik bazı metaforlar 
belirsizlik kategorisi altında toplanmıştır. Yapılan bu araştırmada 1 öğrenci de LGS sınavının gereksiz olduğunu ifade etmiştir. Duban ve Arısoy (2017) tarafından gerçekleştirilen araştırmada da öğrencilerin TEOG sınavının gereksiz olduğuna ilişin metaforlar ürettikleri görülmüştür.

Yapılan çalışmada LGS kavramına ilişkin metaforlar öğrenci algılarına göre incelendiğinden LGS kavramına yönelik öğretmenlerin, okul yöneticilerinin ve veli algılarının da ortaya çıkarıldığı akademik çalışmalar yapılabilir. Her yıl milyonlarca öğrencinin katıldığı merkezî sistem sınavları başarının tek bir sınavla ölçülmesiyle öğrenciler üzerinde stres, kaygı, korku gibi duygu durumları oluşturmak, rekabetçi ortamda yarışmaya zorlanmak, oyun ve sosyal etkinliklerden uzaklaşmak gibi olumsuz etkiler oluşturmaktadır (Karaşahinoğlu, 2015). Çalışmada 8. sınıf öğrencilerinin LGS'ye ilişkin olumsuz algılarının daha fazla olduğu bulgusuna ulaşılmıştır. Alanyazında da merkezi sınavların eğitim sistemi üzerinde olumsuz etkileri olduğunu belirten çalışmalar (Şad ve Şahiner, 2016; Buldur ve Acar, 2019) bulunmaktadır. $\mathrm{Bu}$ sebeple sinavla birlikte öğrencilerin bireysel yetenek ve sosyal etkinliklerinin, okuldaki akademik başarılarının, öğretmen ve veli gözlemlerinin değerlendirmeye alındığı bir değerlendirme sistemi geliştirilebilir. Ayrıca ortaokul öğrencilerinin sınav stresi, kaygısı, korkusu yaşamadan çocukluklarını yaşayabilecekleri ve test kitaplarına değil ilgilerine yönelik aktivitelere zaman ayırabilecekleri bir sınav sistemine ihtiyaç duyulduğu düşünülmektedir.

\section{KAYNAKÇA}

Aslan, N. \& Cansever, B. (2009). Ailenin sosyo-demografik özelliklerinin çocuğun okuldaki sosyal etkinliklere katılımı üzerindeki etkileri: Türkiye ve Hollanda arasında karşılaştırmalı bir çalışma. Ĕ̈itimde Kuram ve Uygulama, 5(2), 210-226.

Aydın, F. (2010). Ortaöğretim öğrencilerinin coğrafya kavramına ilişkin sahip oldukları metaforlar. Kuram ve Uygulamada Ĕ̈itim Bilimleri,10(3), 1293-1322.

Aydın, F. \& Ünaldı, Ü. E. (2010). Coğrafya öğretmen adaylarının "Coğrafya” kavramına ilişkin algılarının metaforlar yardımıyla analizi”. International Online Journal of Educational Sciences, 2(2), 600-622.

Aydoğdu, E. (2008). İlköğretim okullarındaki ögrenci ve öğretmenlerin sahip oldukları okul algıları ile ideal okul algılarının metaforlar (mecazlar) yardımıyla analizi. (Yayınlanmamış Yüksek Lisans Tezi), Osmangazi Üniversitesi, Eskişehir.

Aykaç, N. \& Atar, E. (2014). Geçmişten günümüze ilköğretimden ortaöğretime geçiş sisteminin değerlendirilmesi. Akdoğanbulut-İnsan, A. ve Yavuz-Akengin, A (Eds.),İçinde Cumhuriyet'in kuruluşundan günümüze eğitimde kademeler arası geçiş ve yeni modeller uluslararası kongresi (ss. 83-104). Ankara: Atatürk Kültür, Dil ve Tarih Yüksek Kurumu.

Balc1, A. (2011). Sosyal bilimlerde araştırma yöntem, teknik ve ilkeler, Ankara: Pegem Akademi

Baş, G. \& Kıvılcım, Z. S. (2019). Türkiye'de öğrencilerin merkezi sistem sınavları ile ilgili algıları: bir metafor analizi çalışması. Eğitimde Nitel Araştırmalar Dergisi, 7(2), 639-667.

Berelson, B (1952). Content analysis in communication research, FreePress, Glencoe.

Blake, J. E. (2012). High-stakes testing: A (Mis)construed, Normalizing Gaze International Journal of Educational Policies. 6(1). 5-23.

Bolat,Ö. (2010, 19 Ocak). Önyargıların başarıya etkisi. Hürriyet. Erişim adresi: http://www.hurriyet.com.tr/onyargilarin-basariya-etkisi-13516248

Bökeoğlu, Ö.Ç. \& Özdem, G. (2009). Danimarka lisansüstü öğretim sistemi. Edit: Elife Doğan Kılıç. İçinde Lisansüstü Ögretim Sistemleri (ss.107-132). Ankara. Pegem Akademi.

Buldur, S., \& Acar, M. (2019). Ortaokul öğretmenlerinin merkezi sınavlara yönelik görüşleri. Kastamonu Education Journal, 27(1), 319-330. doi:10.24106/kefdergi.2543.

Büyüköztürk, Ş. (2016). Sınavlar üzerine düşünceler. Kalem Eğitim ve İnsan Bilimleri Dergisi, 6(2), 345356.

Can, E. (2015). Qualitative obstacles in Turkish education system and suggestions. The Anthropologist, 20(1-2), 289-296.

Can, E. (2017). Öğrenci görüşlerine göre merkezi sınavların etkilerinin belirlenmesi. Akademik Sosyal Araştırmalar Dergisi, 5(58), 108-122. 
Çelik, Z. (2011). Ortaöğretime geçiş sınav sistemleri ve politikaları. 21. yüzyılda Türkiye'nin eğitim ve bilim politikalar. 21. Yüzyılda Türkiye'nin Eğitim ve Bilim Politikaları Sempozyumu'nda sunulmuş sözlü bildiri. 10-11 Aralık 2011, Ankara.

Çelik, Z., Boz, N., Arkan, Z. \& Toklucu, D. K. (2017). TEOG yerleştirme sistemi: güçlükler ve öneriler. SETA (Siyaset, Ekonomi ve Toplum Araştırmalarl Vakfi), 94(1). https://www.researchgate.net/publication/320628250 adresinden alınmıştır.

Çepni, S., Özsevgeç, T. \& Gökdere, M. (2003). Bilişsel gelişim ve formal operasyon dönem özelliklerine göre ÖSS fizik ve lise fizik sorularının incelenmesi. Milli Ĕ̆itim Dergisi,157, 30-39.

Çetin, A. \& Ünsal, S. (2019). Merkezi sınavların öğretmenler üzerinde sosyal, psikolojik etkisi ve öğretmenlerin öğretim programı uygulamalarına yansıması. Hacettepe Üniversitesi Eğitim Fakültesi Dergisi, 34(2), 304-323. doi: 10.16986/HUJE.2018040672.

Demir, S. B. \& Yılmaz T. A. (2019). En iyisi bu mu? Türkiye'de yeni ortaöğretime geçiş politikasının velilerin görüsslerine göre değerlendirilmesi. Bolu Abant İzzet Baysal Üniversitesi Ĕgitim Fakültesi Dergisi, 19 (1), 164-183.

Department for Education, England. (2016). Analysis of secondary school level application sandoffers data by schooltype. Retrived from: https://assets.publishing.service.gov.uk/ government/uploads/system/uploads/attachment_data/file/

Dinç, E., Dere, İ. \& Koluman, S. (2014). Kademeler arası geçiş uygulamalarına yönelik görüş ve deneyimler. Adiyaman Üniversitesi Sosyal Bilimler Enstitüsü Dergisi, 7(17), 397-423.

Dönmez, B. (2017). Türkiye'de temel eğitimden ortaöğretime geçiş sistemine ilişkin bir değerlendirme. Ĕgitime Bakış: Ĕgitim-Öğretim ve Bilim Araştırma Dergisi, 13(40), 26-31.

Duban, N. \& Arısoy, H. (2017). 8. sınıf öğrencilerinin temel eğitimden orta öğretime geçiş (TEOG) sınavına ilişkin algılarının metaforlar aracılığılyla incelenmesi. Kalem Eğitim ve İnsan Bilimleri Dergisi, 7(1), 67-98.

Eren, A. \& Tekinarslan, E. (2013). Öğretmen, öğretme, öğrenme, öğretim materyali ve değerlendirmeye ilişkin metaforlar: yapısal bir analiz. Gaziantep University Journal of Social Sciences 12(3), 443-467.

Ergün, M. (2014). Eğitimde kademelerin oluşması ve kademeler arası geçiş düzenlemelerine tarihi bakış. Cumhuriyet'in kuruluşundan günümüze eğitimde kademeler arası geçiş ve yeni modeller uluslararası kongresi. Atatürk Kültür, Dil ve Tarih Yüksek Kurumu Atatürk Araştırma Merkezi.

Erözkan A. (2004). Üniversite öğrencilerinin sınav kaygısı ve başaçıkma davranışları. Muğla Üniversitesi Sosyal Bilimler Enstitüsü Dergisi, 13-38.

Eurypedia.(2013). The structure of the European education systems 2013/14:schematicdiagrams.Retrivedfromhttp:

http://www.indire.it/lucabas/lkmw_file/eurydice/education_structures_2013_EN.pdf

Girmen, P. (2007). Illkögrretim öğrencilerinin konuşma ve yazma sürecinde metaforlardan yararlanma durumları. (Yayınlanmamış Doktora Tezi), Anadolu Üniversitesi Eğitim Bilimleri Enstitüsü, Eskişehir.

Görmez, M. \& Coşkun, İ. (2015). 1. Yllında temel eğitimden ortaöğretime geçiş reformunun değerlendirilmesi. SETA/Siyaset, Ekonomi ve Toplum Araştırmaları Vakfi,114,121.http://file.setav.org/Files/Pdf/20150115172839_1.-yilinda-temel-egitimdeortaogretime-gecisreformunun-degerlendirilmesi-pdf.pdfadresinden alınmıştır.

Güler, M., Arslan, Z. \& Çelik, D. (2019). 2018 Liselere giriş sınavına ilişkin matematik öğretmenlerinin görüşleri. YYÜ Eğitim Fakültesi Dergisi, 16(1):337-363.http://dx.doi.org

Güngör-Aytar, F. A. \& Kurtoğlu-Karataş, B. (2017). Lise öğrencilerinin “üniversitesi sınavı” kavramına iliş̧in metaforik algılarının incelenmesi. O. N. Akfırat, D. F. Staub ve G. Yavaş (Eds.), Currentdebates in education 5, 63-80. London: IJOPEC Publication.

Gür B., S., Çelik Z., \& Coşkun İ. (2013). Türkiye'de ortaöğretimin geleceğii: Hiyerarşi mi, eşitlik mi? SETA Siyaset, Ekonomi ve Toplum Araştırmaları Vakfi. 69, 1-28 http://file.setav.org/Files/Pdf/20130802120003.http://file.

setav.org/Files/Pdf/20130802120003_ortaogretim_analiz2.pdf adresinden alınd1.

Güven, S. \& Dak, G. (2017). Öğretmen adaylarının kamu personeli seçme sınavına (KPSS) ilişkin oluşturdukları görsel metaforlar. Ĕgitim ve İnsani Bilimler Dergisi: Teori ve Uygulama, 8(15), 1- 16. 
İnanç, B. Y. \& Hanımoğlu, E. (2011). Seviye belirleme sınavına girecek olan ilköğretim ikinci kademe öğrencilerinde sınav kaygısı, mükemmeliyetçilik ve anne-baba tutumu arasındaki ilişkinin incelenmesi. Çukurova Üniversitesi Sosyal Bilimler Enstitüsü Dergisi, 20(1), 351-366.

Jain, C. \& Prasad, N. (2017). Indian education system: structure and key challenges. Quality of Secondary Education in India, 67-78. doi:10.1007/978-981-10-4929-3_7.

Janis I, L (1949) The problem of validating content analysis. H.D. Lasswell \& (eds), The Language of Politics: Studies in Quantitative Semantics, George Stewart. New York, 55-82.

Jones, M. G., Jones, B. D., Hardin, B., Chapman, L., Yarbrough, T. \& Davis, M. (1999). Impact of highstakestesting on teachers and students in North Carolina. Phi Delta Kappan, 81, 199-203.

Karadeniz, O., Er, H. \& Tangülü, Z. (2014). 8. sınıf öğrencilerinin SBS’ye yönelik metaforik algıları. Uluslararası Avrasya Sosyal Bilimler Dergisi, 5(15), 64-81.

Karaşahinoğlu A. (2015). Öğrencilerin metaforik sınav algıları ile velilerin okula yönelik görüşleri arasındaki ilişki. (Yayımlanmamış Yüksek LisansTezi), Ankara Üniversitesi, Ankara.

Koçak, D., Doğan Gül, Ç., Gül, E. \& Çokluk Bökeoğlu, Ö. (2017). Öğrencilerin sınav kavramına yönelik metaforlarının incelenmesi. Ahi Evran Üniversitesi Kırşehir Eğitim Fakültesi Dergisi, 18(3), 415-434.

Lakoff, G. \& Johnson, M. (1980). Metaphors we live by. Chicago, IL: University of Chicago Press.

Linn, R. L. A. \& Gronlund, N. E. (1995). Measurementandassessment in teaching (7th ed.). New Jersey: PrenticeHall.

Milli Eğitim Bakanlığı (MEB) (2018). Sinavla öğrenci alacak ortaöğretim kurumlarına ilişkin merkezi sinav başvuru ve uygulama kllavuzu. Ankara: Milli Eğitim Bakanlığıhttps:www.meb.gov.tr/sinavlar/dokumanlar/2018/MERKEZİ $\quad$ SINAV _BASVURU_VE_UYGULAMA_K ILAVUZU.pdf'den indirilmiştir.

Millî Eğitim Bakanlığı (MEB) (2018). https://www.meb.gov.tr/lgs-kapsamindaki-merkezi-sinav-1hazirandayapilacak/ haber/17534/tr adresinden alınd1.

Millî Eğitim Bakanlığı Ortaöğretim Kurumları Yönetmeliğinde Değişiklik Yapılmasına Dair Yönetmelik. http://www.resmigazete.gov.tr/eskiler/2018/02/2018 adresinden alınd1.

Miles, M. B. \& Huberman, A. M. (1994). Qualitative data analysis: an expandedsourcebook. (2. bask1). Calif.: SAGE Publications.

Morgan, G., (1998). Yönetim ve örgüt teorilerinde metafor. (Çev. G. Bulut). İstanbul: Mess.

Ocak, G., Akgül, A. \& Yıldız, S. S. (2010). İlköğretim öğrencilerinin ortaöğretime geçiş sistemi'ne (OGES) yönelik görüşleri (Afyonkarahisar örneği). Journal of KirsehirEducation Faculty, 11(1), 37-55.

Oğuz, A. (2005). Öğretmen eğitim programlarında metafor kullanma. H. Kıran, (Ed.), XIV. Ulusal Eğitim Bilimleri Kongresi. Pamukkale Üniversitesi, Eğitim Fakültesi, Denizli, 582-588.

Öztürk, F. Z. \& Aksoy, H. (2014). Temel eğitimden ortaöğretime geçiş modelinin 8. Sınıf öğrenci görüsslerine göre değerlendirilmesi (Ordu ili örneği). Ondokuz Mayıs Üniversitesi Eğitim Fakültesi Dergisi, 33(2), 439-454.

Saban, A. (2008). Okula ilişkin metaforlar. Kuram ve uygulamada eğitim yönetimi, 55, 459-496.

Sarı, E. (2016). Okulda başarılı olmak. Antalya: Nokta E-Book Publishing.

Sarıer, Y. (2010). Ortaöğretime giriş sınavları (OKS-SBS) ve PISA sonuçları 1şığında eğitimde fırsat eşitliğinin değerlendirilmesi. Ahi Evran Üniversitesi Ĕ̈itim Fakültesi Dergisi, 11(3), 107-129.

Semerci, Ç. (2007). Program geliştirme kavramına ilişkin metaforlarla yeni ilköğretim programlarına farklı bir bakış. Cumhuriyet Üniversitesi Sosyal Bilimler Dergisi, 31 (2), 125-140.

Şad, S. N. \& Şahiner, Y. K. (2016). Temel eğitimden ortaöğretime geçiş (TEOG) sistemine ilişkin öğrenci, öğretmen ve veli görüşleri. İlkögretim Online, 15(1), 53-76.

Şahin, S., Uz Baş, A., Şahin Fırat, N. \& Sucuoğlu, H. (2012). İlköğretim okulu öğrenci ile öğretmenlerinin ortaöğretime geçiş sistemine ilişkin görüşleri. International Journal of Human Sciences, 9(2), 847-878

Tarhan, Ö. (2015). Sosyal bilgiler öğretmeni adaylarının politik okuryazarlığa ilişkin görüşleri. Akademik Sosyal Araştırmalar Dergisi, 9, 649-669.

Tuncer, M. (2017). Seçme ve yerleştirme sorunsalı ve TEOG (temel eğitimden ortaöğretime geçiş) sinavı. Eğitime Bakış: Ĕgitim-Öğretim ve Bilim Araştırma Dergisi, 13(40), 50-55. 
Uşaklı H, Yapıcı Ş. (2001). Grup rehberliğinin sınav kaygısına etkisi üzerine öğrenci görüşleri. Akdeniz Üniversitesi Sosyal Bilimler Dergisi, 2.

$\mathrm{Wu}, \mathrm{Y} .(2015)$. The examination system in china: the case of zhongkao mathematics. Selected Regular Lectures from the 12th International Congress on Mathematical Education, 897-914. https://doi.org/10.1007/978-3-319-17187-6_50

Yavuz, M. (2010). A Study on variables that affect classscores of primary education students in placement test. ElementaryEducation Online, 9(2), 705-713.

Yıldııım, A. \& Şimşek, H. (2008). Sosyal bilimlerde nitel araştırma yöntemleri. Ankara: Seçkin Yayıncılık.

Yıldız, A. \& Ünlü, D. (2014). Eleştirel eğitim seçkisi. Edit: N. Samet Baykal, Ayhan Ural, Zeynep Alica, İçinde Metaforlarla ögretmenliğin dönüşümü: "Dün heybetli bir şelaleydik, bugün ise kurumaya yüz tutmuş dere”. 56-67. Ankara: PegamA. Yay.

\section{EXTENDED ABSTRACT}

Introduction: The exam is used as a criterion to measure learning and assess success (Linn ve Gronlund, 1995). According to Çepni, Özsevgeç and Gökdere (2003), the evaluation of students by their teachers in the schools where they receive formal education is local evaluation; the evaluation by central institutions such as the Ministry of National Education (MEB), Student Selection and Placement Center (ÖSYM) is central evaluation. One of the most important examples of the central assessment is the LGS, which is aimed at placing secondary school students in various high schools. Students are placed in high schools as a result of the score they get from LGS. With LGS, the classification of schools in terms of quality, the placement of very few students in schools classified as qualified, and the competition of students in order to enter these small numbers of students bring some problems in the education system (Demir ve Y1lmaz, 2019). Dinç, Dere and Koluman (2014) there is a very high number of students taking the examination in Turkey, stated that the training of secondary school for reasons such differentiation in terms of quality central examination is necessary. Metaphor is the expression of a person or concept by using analogies (Aydin, 2010). To determine perceptions of one grip in recent years in Turkey are observed to be the metaphor work. Metaphors are one of the ways that make the student think (Oğuz, 2005).

Turkey in the 8th grade students who applied before the SBS, including their views on the TEOG studies in the literature although they are metaphors for the first time as determined by the previous administration in 2018 to LGS perceptions are no studies. Although there are researches about the opinions of parents and branch teachers about LGS, the fact that there are no metaphorical analysis of the opinions of 8th grade students where LGS is applied creates a deficiency in the literature. It is thought that the research will fill the deficiency in the literature. In line with the stated importance, the aim of the study is to reveal 8th grade students' perceptions about LGS through metaphors. In line with this purpose, the following questions about the LGS concept will be answered in this study.

1-What are the metaphors that students create about LGS?

2-Under what categories can the metaphors developed by the students regarding LGS concept be combined in terms of their common characteristics?

Materials and Methods: Phenomenology was used in this study which is a qualitative research. The population of the research is 8th grade students in secondary schools in Mamak district in 2019/2020 academic year. The study group consisted of 175 8th grade students who were selected by random sampling method in two secondary schools in Mamak center, which was selected by easy sampling method which provides ease of access and time saving. Activity form was used as a data collection tool, which is including the expression 'LGS is like ..., because it is ...'. The data were analyzed by content analysis method.The categories were formed by reading each metaphor and its cause one by one.Then metaphors were evaluated in their own categories. In order to ensure the validity of the research data, expert opinion was used and in order to ensure reliability, the reliability calculation formula of Miles and Huberman (1994) was used. The reliability of the formula was calculated as $\% 98.70$.

Findings: Students participating in the study developed a total of 77 metaphors forthe LGS concept. These metaphors are grouped under six conceptual categories. When 77 metaphors for LGS are categorized by students, it is seen that the most metaphors related to LGS are gathered under the category 'LGS as Disturbance / Difficulty (\% 38.96)' This category is followed by LGS as struggle / effort / labor (\% 23.38), LGS as the starting / important / turning point (\% 15.57), and LGS as the future / guiding (\% 14.29).The metaphors for LGS are 
categorized the least under the category of LGS as failure (\% 3.90) and LGS as the uncertainty / necessity (\% 3.90). The first conceptual category of the study regarding the metaphor of centralized system examinations is LGS as a disturbing / difficult situation.This category is the most metaphor-generatedcategory, as 70 out of 175 studentsproduce 30 (\% 38.96) of the total 77 metaphors. These condconceptual category for the LGS metaphor is 'LGS as struggle / effort / labor'.In this category, 26 students produced 17 (\% 23.38) of the total 77 metaphors. When the metaphors produced by the students regarding the LGS were examined in the second conceptual category, it was found that the metaphors produced were generally dependent on effort and effort which required struggle for the students.

The third conceptual category for the LGS metaphor is 'LGS as a starting / important / milestone'. In this category, 25 students produced 12 (\% 15.57) of the total 77 metaphors. When the metaphors produced by the students about LGS are analyzed, it is seen that the metaphors produced are very important by the students in general and they are a turning point and a beginning in their lives. The fourth category of the LGS metaphor is 'LGS as a future / guide'.In this category, 48 students produced 11 (\% 14.29) of the total 77 metaphors produced. The fifth conceptual category forthe LGS metaphor is 'LGS as failure'.In this category, 3 students produced 3 (\% 3.95) metaphors. It was understood that the metaphors produced in the fifth category evoke failure for the students. The sixth conceptual category for the LGS metaphor is 'LGS as uncertainty / unnecessary'. In this category, 3 students produced 3 (\% 3.95) metaphors. As it is seen in the metaphors produced in the sixth category, students consider LGS as an unnecessary and absurd exam, it is a situation that create suncertainty.

Discussion, Conclusion and Suggestions: In this study, 8th grade students thoughts about LGS were tried to be put forward through metaphors. The students who participated in the study produced a total of 77 metaphors related to LGS.These metaphors are; 'LGS as a disturbing / challenging situation (\% 38.96), LGS as a struggle / effort / labor (\% 23.38), LGS as a starting / important / milestone (\% 15.57), LGS as a future / guiding (\% 14.29), LGS as a failure (\% 3.90) and LGS as an uncertainty (\% 3.90). They grouped under a total of six conceptual categories collected under.

When the metaphors produced by the students related to LGS were examined, it was found that the metaphors produced were generally stress, fear, anxiety, difficulty and discomfort for the students. In the literature, there are studies indicating that exams, especially central exams, cause stress and anxiety in students. Yavuz (2010), Ocak, Akgül and Yıldız (2010), Şahin, UzBaş, ŞahinFırat and Sucuoğlu (2012), Karadeniz, Er and Tangülü (2014), Dinç et al. (2014), Demir and Yılmaz (2019) Şad and Şahiner (2016) and Jones et al. (1999, p.201) are some of them. Another finding obtained from the study is that LGS requires struggle and effort. Baş and K1vilcım (2019) examined the metaphors produced by the students related to the central system exams, and concluded that the metaphors produced required effort and work for the students in general. Another research finding is that LGS is an important and turning point for students. According to Sar1 (2016), the central examination system in Turkey, which means turning point that will determine the future for students. Another research finding is that LGS determines students's future. Karaşahinoğlu's (2015) Çelik's (2011), İnanç and Hanımoğlu's studies support this finding. The finding that LGS is perceived as failure is Çetin and Ünsal (2019) and the finding of uncertainty / necessity is supported by Baş and Kıvılcım (2019). In this study, metaphors related to LGS concept were examined according to student perceptions. Academic studies can be conducted to reveal the perceptions of teachers and parents towards LGS. In particular, in an education system where all schools are qualified, an evaluation system can be developed in which individual talent and socialactivities of students, teacher, school administrators and parent observations are evaluated. 